\title{
PENENTUAN MUTU IKAN TANDIPANG (Dussumieria acuta C.V) ASAP KERING SELAMA PENYIMPANAN SUHU KAMAR
}

\author{
Rita Kaparang, Silvana D Harikedua dan I Ketut Suwetja
}

Fakultas Perikanan dan Ilmu Kelautan, Universitas Sam Ratulangi, Manado, Sulawesi Utara.

\begin{abstract}
ABSTRAK
Ikan japuh (Dussumieria acuta C.V) dikenal dengan nama lokal tandipang merupakan salah satu jenis ikan yang dihasilkan dari proses pengeringan yang dikombinasikan dengan pengasapan. Produk ini memberikan citarasa tersendiri yang lezat, gurih dengan aroma yang khas disebabkan oleh proses pengasapan. Penelitian ini bertujuan untuk mengetahui perubahan mutu ikan tandipang asap kering selama penyimpanan. Hasil yang di dapat bahwa nilai kadar air tertinggi adalah 15,70\% pada ikan tandipang asap kering yang disimpan 40 hari. Sedangkan nilai kadar air terendah adalah 15,20\% pada ikan tandipang asap kering tanpa penyimpanan. Untuk nilai $\mathrm{pH}$ tertinggi adalah 6,63 pada ikan tandipang asap kering yang disimpan 40 hari dan nilai $\mathrm{pH}$ terendah adalah 6,06 pada ikan tandipang asap kering tanpa penyimpanan. Nilai TVB yang tertinggi adalah $96,60 \mathrm{mg} \mathrm{N} / 100 \mathrm{gr}$ sampel pada ikan tandipang asap kering yang disimpan selama 40 hari dan nilai TVB-N terendah adalah 64,80 mg N/100 gr sampel pada ikan tandipang asap kering tanpa penyimpanan. Nilai uji hedonik nilai tertinggi adalah 7,17 pada ikan tandipang asap kering tanpa penyimpanan, sedangkan nilai terendah adalah 6,47 pada ikan tandipang asap kering penyimpanan selama 40 hari. Proses pengasapan dan pengeringan dapat mempertahankan mutu ikan tandipang asap kering sampai pada penyimpanan selama 40 hari dengan kadar air, $\mathrm{pH}$ dan TVB yang rendah serta tingkat kesukaan panelis terhadap produk masih disukai panelis selama penyimpanan 40 hari.
\end{abstract}

Kata kunci: tandipang, asap kering, suhu, Dussumieria.

\section{PENDAHULUAN}

Industri pengolahan ikan tandipang asap kering merupakan suatu usaha kecil yang banyak dikelola masyarakat pesisir pantai yang ada di Kecamatan Tumpaan. Data tahun 2008 dari Dinas Kelautan dan Perikanan Kabupaten Minahasa Selatan menunjukkan bahwa rata-rata hasil produksi ikan tandipang asap kering adalah 29,4 kg/hari. Data ini diambil berdasarkan data 11 unit pengolah ikan tandipang asap kering (Anonimous, 2008).

Ikan tandipang (Dussumieria acuta C.V) merupakan salah satu jenis ikan yang banyak diolah sebagai ikan asap kering dan dikenal dengan nama ikan tandipang asap kering yang dihasilkan dari proses pengeringan yang dikombinasikan dengan pengasapan. Produk ini memberikan citarasa tersendiri yang lezat, gurih dengan aroma yang khas disebabkan oleh adanya kombinasi proses pengeringan pengasapan tersebut. Batas penyimpanan dari ikan tandipang asap kering belum diketahui. Penurunan mutu selama penyimpanan ditandai dengan adanya bau tengik, citarasa yang tidak enak dan munculnya jamur.
Sampai saat ini belum terdapat dokumentasi ilmiah tentang mutu ikan tandipang asap kering selama penyimpanan yang diolah oleh industri rumah tangga. Berdasarkan hal-hal tersebut, maka dirasa perlu untuk melakukan penelitian tentang penentuan mutu ikan tandipang asap kering selama penyimpanan suhu kamar. Hasil penelitian ini diharapkan dapat memberikan informasi terhadap perubahan mutu ikan tandipang asap kering selama penyimpanan 40 hari.

\section{METODOLOGI PENELITIAN}

Metode yang digunakan dalam penelitian adalah metode deskriptif yaitu penelitian yang memberikan pengamatan secermat mungkin suatu individu, keadaan atau sifat-sifat secara sistematis dan aktual. (Suryabrata 1994 dalam Bawangun, 2003). Bahan baku yang digunakan pada penelitian ini adalah ikan tandipang segar. Gambar 1 menyajikan proses pengolahan ikan tandipang menjadi ikan tandipang asap kering sampai siap untuk dianalisa. Bahan kimia yang digunakan untuk analisa laboratorium adalah akuades, larutan Trichloroacetic Acid (TCA) 7,5\%, asam 
borat $\left(\mathrm{H}_{3} \mathrm{BO}_{3}\right) 1 \%$, indikator (methyl red dan bromo cresol green) kalium karbonat $\left(\mathrm{K}_{2} \mathrm{CO}_{3}\right)$, $\mathrm{HCl} 0,02 \mathrm{~N}$ dan vaselin. Peralatan yang digunakan antara lain adalah rak, alat pengasapan ikan, lemari pengering, termometer, oven, desikator, timbangan analitik, cawan porselin, $\mathrm{pH}$ meter, gelas ukur, mortar, pipet, tabung reaksi, cawan conway, buret, booth, piring dan label.

Data yang diperoleh dengan menentukan rata-rata dari tiap pengamatan, ditambah, standar deviasi dan disajikan dalam bentuk tabel. Parameter yang diuji adalah kadar air, pH, Total Volatile Base (TVB) dan organoleptik.

Analisa kadar air (Sudarmadji $d k k$., 1984)

Analisa kadar air dilakukan dengan menggunakan metode oven, kadar air dihitung sebagai persen berat, artinya berapa gram berat contoh, dengan selisih berat dari contoh yang belum diuapkan dengan contoh yang telah diuapkan (dikeringkan). Sampel yang berupa serbuk atau bahan yang telah dihaluskan sebanyak 1-2 gram dalam cawan ditimbang beratnya. Sampel dikeringkan dalam oven pada suhu $100-105^{\circ} \mathrm{C}$ selama $3-5$ jam. Kemudian didinginkan dalam desikator dan ditimbang. Dipanaskan lagi dalam oven, didinginkan dalam desikator dan ditimbang; perlakukan ini diulangi sampai tercapai berat konstan. Kadar air dihitung dengan pengurangan berat merupakan banyaknya air dalam bahan.

\section{Analisis derajat keasaman (pH) (Harikedua,} 2002)

Penentuan $\mathrm{pH}$ dapat dilakukan dengan menggunakan $\mathrm{pH}$ meter. Sampel yang telah dirajang kecil-kecil sebanyak $10 \mathrm{~g}$ ditimbang dan dihomogenkan (diblender) dengan $20 \mathrm{ml}$ akuades selama 1 menit. dituangkan ke dalam beker glass $100 \mathrm{ml}$, kemudian diukur pHnya dengan menggunakan $\mathrm{pH}$ meter. Sebelum $\mathrm{pH}$ meter digunakan untuk mengukur $\mathrm{pH}$ sampel, $\mathrm{pH}$ harus ditera kepekaan jarum penunjuk $\mathrm{pH}$ meter dengan larutan buffer $\mathrm{pH} 4$, kemudian dengan larutan buffer 7 . Besarnya harga $\mathrm{pH}$ adalah pembacaan jarum penunjuk $\mathrm{pH}$ setelah jarum skala konstan kedudukannya.

\section{Analisa TVB (Suwetja, 1993)}

Metode analisa TVB ditetapkan dengan metode conway. Penyiapan ekstraksi daging sampel dilakukan dengan menimbang $5 \mathrm{~g}$ daging ikan, dihancurkan dalam sebuah mortar dengan menambahkan $10 \mathrm{ml}$ larutan TCA 7,5 $\%$. Setelah hancur rata, dibiarkan dalam temperatur ruangan selama kira-kira 30 menit. Jika temperatur ruangan lebih tinggi dari $30^{\circ} \mathrm{C}$, pekerjaan ini dilakukan pada suhu yang lebih rendah yaitu didinginkan dengan meletakkan mortar pada air es. Selanjutnya, ekstraksi daging ikan disaring dengan kertas saring (no. 2-3). Bila analisa selanjutnya tidak bisa segera dilakukan, larutan ekstraksi ini dapat disimpan dalam ruang pendingin dengan $-20--30^{\circ} \mathrm{C}$.

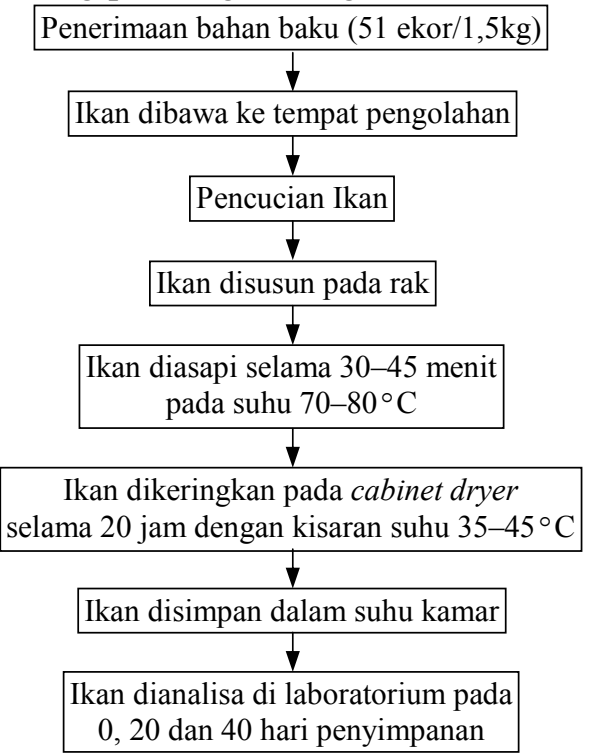
Gambar 1. Proses pengolahan ikan tandipang
asap kering.

Sebanyak $1 \mathrm{ml}$ larutan $\mathrm{H}_{3} \mathrm{BO}_{3} \quad 1 \%$ dan beberapa tetes larutan indikator dipipet ke inner chamber, kemudian $1 \mathrm{ml}$ larutan ekstrak daging ikan dipipet ke outer chamber. Setelah itu, penutup cawan yang permukaannya telah diolesi rata dengan vaselin, diletakkan pada rumahnya dengan posisi sedikit terbuka. Selanjutnya, $1 \mathrm{ml} \mathrm{K}{ }_{2} \mathrm{CO}_{3}$ jenuh dipipet ke outer chamber bagian lain, kemudian cawan ditutup rapat dan diputar perlahan sampai larutan sampel bercampur dengan $\mathrm{K}_{2} \mathrm{CO}_{3}$ jenuh. Bersamaan dengan pekerjaan di atas dibuat blanko, dimana sebagai pengganti larutan ekstraksi daging ikan dipakai larutan TCA. Cawan disimpan dalam inkubator dengan suhu $37^{\circ} \mathrm{C}$ selama 80 menit atau dalam suhu kamar selam $24 \mathrm{jam}$. Titrasi bagian inner chamber dengan menggunakan larutan $\mathrm{HCl} 0.02 \mathrm{~N}$. Titik akhir titrasi adalah pada saat $\mathrm{H}_{3} \mathrm{BO}_{3}$ kembali berwarna merah muda kemudian dicatat berapa banyak $(\mathrm{ml})$ asam klorida yang digunakan untuk mentitrasi. 


\section{Pengujian organoleptik}

Berhimpon $d k k ., 2002$ )

Untuk pengujian

(modifikasi

organoleptik

digunakan uji tingkat kesukaan (hedonik) untuk nilai rasa. Contoh diberi nomor kode dan disajikan secara acak. Lima belas orang panelis diminta menilai menurut tingkat kesukaannya berdasarkan skala hedonik yang telah disediakan pada formulir. Setiap panelis menandai ungkapan pada formulir yang sesuai dengan penilaiannya terhadap contoh.

\section{HASIL DAN PEMBAHASAN}

\section{Kadar air}

Nilai kadar air tertinggi adalah 15,70\% pada ikan tandipang asap kering yang disimpan 40 hari, sedangkan nilai kadar air terendah adalah $15,20 \%$ pada ikan tandipang asap kering tanpa penyimpanan. Hasil analisa kadar air pada produk ikan roa asap memperlihatkan nilai kadar air sebesar 22,98\% (Tadanugi, 2004), selanjutnya penelitian oleh Bawangun terhadap ikan teri asap kering menunjukkan nilai kadar air sebesar 14,06\%. Hal ini menunjukkan bahwa kombinasi proses pengasapan dan pengeringan ikan dapat menghasilkan produk dengan kadar air yang lebih rendah.

Menurut Wibowo (2000) perubahan kadar air pada proses pengasapan diakibatkan karena panas dan penarikan air dari jaringan tubuh ikan oleh penyerapan berbagai senyawa kimia dari asap. Selanjutnya menurut Desroiser (1988) proses pengeringan didasari atas terjadinya penguapan (pengisapan) air oleh udara sebagai akibat perbedaan kandungan uap air antara udara dan produk yang dikeringkan.

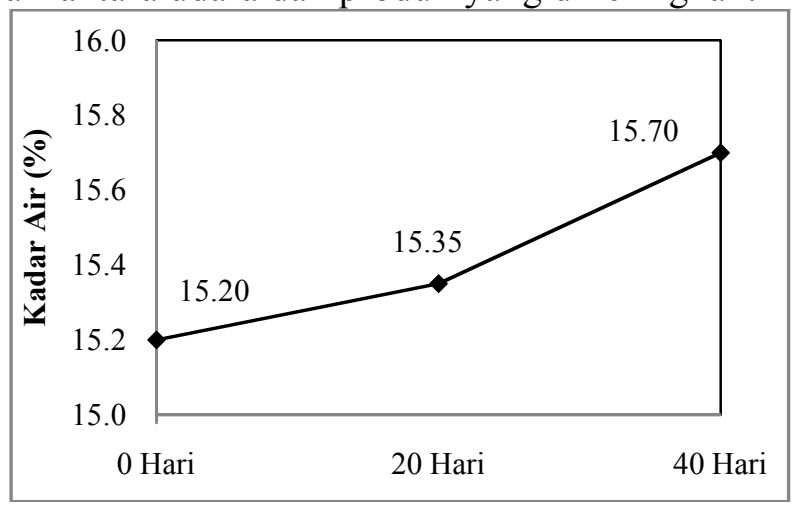

Gambar 1. Hubungan nilai kadar air dan lama penyimpanan ikan tandipang asap kering.

Gambar 1 menunjukkan nilai rata-rata kadar air sejak 0-40 hari penyimpanan. Gambar tersebut menunjukkan bahwa kadar air produk cenderung meningkat selama proses penyimpanan, tetapi masih pada kisaran $15 \%$. Hal ini diduga terjadi karena produk yang dihasilkan dari proses pengasapan dan pengeringan dapat menghilangkan kandungan air sampai batas tertentu dalam daging ikan sehingga menghambat aktivitas mikroba karena air merupakan media yang baik untuk pertumbuhan mikroba yang dapat menurunkan daya awet produk. Afrianto dan Liviawaty (1985) menyatakan bahwa pengawetan ikan dengan pengasapan merupakan salah satu upaya yang dilakukan manusia dalam memperpanjang daya simpan ikan. Di sisi lain menurut Moeljanto (1992) pada proses pengeringan kandungan air dapat diturunkan sampai 30\% sehingga aktivitas bakteri akan terhambat. Selanjutnya menurut Buckle et al. (1985) pada proses pengeringan kadar air bahan dapat berkurang dari $60 \%-10 \%$.

Kadar air ikan tandipang asap kering selama penyimpanan dari 20 hari ke 40 hari cenderung meningkat. Hal ini diduga disebabkan oleh karena kelembaban ruangan yang tinggi, dan mengakibatkan produk menyerap air dari lingkungan. Peningkatan kadar air ini mempengaruhi tingkat kesukaan dari panelis terhadap produk. Produk yang telah disimpan 40 hari memiliki skor kesukaan yang lebih rendah jika dibandingkan dengan produk tanpa penyimpanan. Menurut Purnomo (1995) naiknya kadar air disebabkan karena kelembaban ruangan penyimpanan lebih tinggi dari produk sehingga produk akan menyerap air yang mengakibatkan kadar air produk tinggi. Secara umum, nilai kadar air ikan tandipang asap kering sampai penyimpanan 40 hari masih rendah jika dibandingkan dengan kadar air yang disyaratkan SNI untuk ikan teri asin kering yaitu maksimal 20\% (SNI 2708.1-2009) dan untuk ikan asap maksimal 60\% (SNI 2725.12009).

\section{pH}

Nilai $\mathrm{pH}$ tertinggi adalah 6,63 pada ikan tandipang asap kering yang disimpan 40 hari dan nilai $\mathrm{pH}$ terendah adalah 6,06 pada ikan tandipang asap kering tanpa penyimpanan. Penelitian sebelumnya oleh Lakoro (2009) menunjukkan nilai $\mathrm{pH}$ ikan roa asap pada perlakuan pencucian dengan air tawar adalah 6,06 , sedangkan hasil penelitian Tubagus (2000) terhadap fillet ikan cucut asap menunjukkan nilai $\mathrm{pH}$ 5,58. Selanjutnya, penelitian oleh Walewangko

(1998) 
menunjukkan nilai $\mathrm{pH}$ ikan cucut kering pada perlakuan tanpa arang aktif dari tempurung kelapa adalah 5,98. Nilai pH rendah dari ikan tandipang asap kering ini, diduga merupakan hasil dari proses kombinasi pengasapan dan pengeringan. Proses kombinasi ini akan menghasilkan produk yang lebih awet karena proses kemunduran mutunya lebih lambat.

Menurut Winarno dkk. (1988) bahanbahan asap seperti formaldehida, aseton dan fenol mempunyai sifat membunuh bakteri, sementara asam yang mudah menguap dalam asap akan menurunkan $\mathrm{pH}$ pada permukaan daging ikan dan memperlambat pertumbuhan mikro organisme. Selanjutnya Ilyas (1972), menyatakan bahwa akibat dari proses pengasapan dapat menyebabkan turunnya kadar air, tetapi naiknya kadar asam dan adanya pengendapan berbagai senyawa kimia asap.

Gambar 2 menunjukkan peningkatan nilai $\mathrm{pH}$ ikan tandipang asap kering selama penyimpanan. Berdasarkan gambar tersebut dapat diketahui bahwa selama penyimpanan 0 hari sampai 40 hari mengalami peningkatan yang tidak signifikan. Hal ini diduga karena aktivitas enzim pengurai belum bekerja efektif sehingga $\mathrm{pH}$ naik tapi tidak signifikan. Chamidah (2000) menyatakan bahwa selama penyimpanan terjadi penguraian protein menjadi senyawa basa antara lain amoniak. Nilai pH bahan pangan selama penyimpanan dapat berubah karena adanya protein yang terurai oleh enzim proteolitik dan bantuan bakteri menjadi asam karboksilat, asam sulfida, amoniak dan jenis asam lainnya. Menurut Zakaria (1996) bila jumlah asam lebih banyak dari amoniak maka nilai $\mathrm{pH}$ menjadi rendah. Oleh karena itu nilai $\mathrm{pH}$ ikan tandipang asap kering yang dihasilkan walaupun meningkat tetapi masih pada kondisi asam. Perubahan nilai $\mathrm{pH}$ ini juga mempengaruhi tingkat kesukaan panelis terhadap produk.

\section{TVB (Total Volatile Base)}

Nilai TVB-N ikan tandipang asap kering selama penyimpanan memperlihatkan nilai yang bervariasi. Nilai TVB-N tertinggi adalah 96,60 mg N/100 g sampel pada ikan tandipang asap kering yang disimpan selama 40 hari dan nilai TVB-N terendah adalah 64,80 $\mathrm{mgN} / 100 \mathrm{~g}$ sampel pada ikan tandipang asap kering tanpa penyimpanan.

Berdasarkan tabel di atas dapat diketahui bahwa nilai TVB-N ikan tandipang asap kering tanpa penyimpanan adalah $\pm 54,80$ mg N/100 g. Hasil penelitian sebelumnya oleh Azam et al. (2003) terhadap 4 spesies ikan yang dikeringkan yaitu Mugil cephalus, Scoliodonshorrakowah, Harpodon nejerus dan Setipinna phasa dan ditangkap pada musim panas menunjukkan nilai TVB-N sebagai berikut: 62,$22 ; 62,4 ; 33,1$; dan 46, $21 \mathrm{mg} \mathrm{N} / 100$ g sampel.

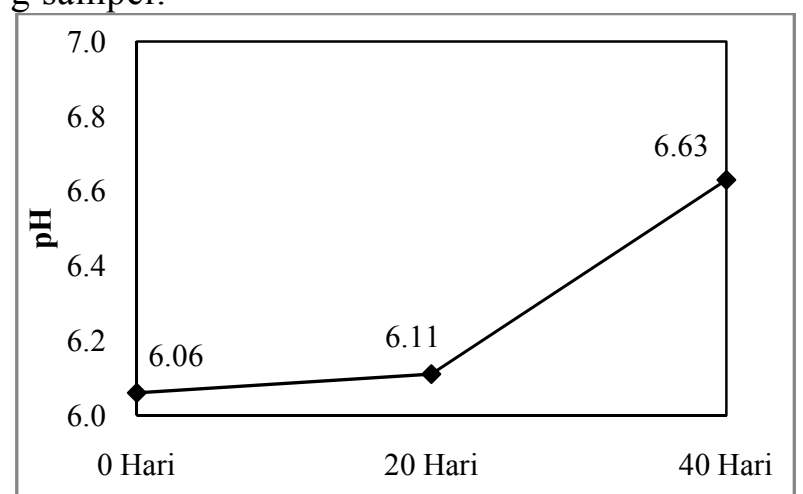

Gambar 2. Hubungan Nilai pH dan Lama Penyimpanan Ikan Tandipang Asap Kering

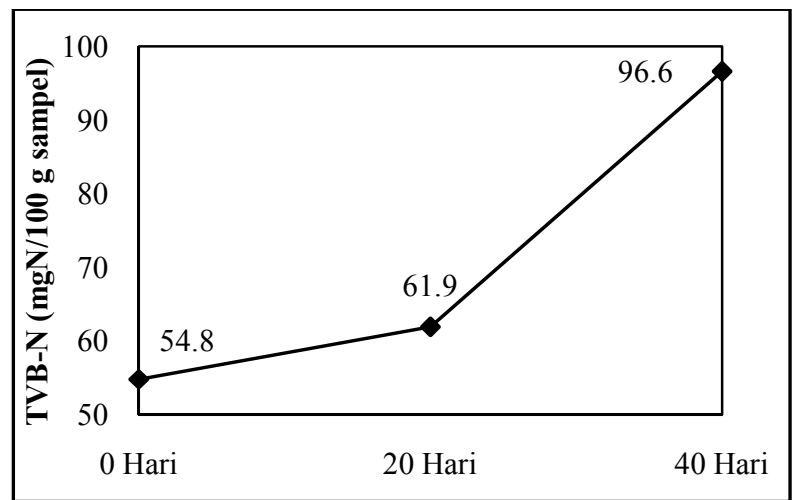

Gambar 3. Hubungan Nilai TVB-N dan Lama Penyimpanan Ikan Tandipang Asap Kering

Gambar 3 menunjukkan perubahan nilai TVB-N ikan tandipang asap kering selama penyimpanan. Berdasarkan gambar tersebut dapat dilihat bahwa semakin lama penyimpanan nilai TVB-N ikan tandipang cenderung meningkat. Hal ini kemungkinan terjadi karena aktivitas enzim pengurai mulai bekerja.

Menurut BPPMHP (2005) dalam Nurcahya dan Ibrahim (2008) sampai saat ini belum ada standar kadar TVB-N produk olahan perikanan yang berkaitan dengan mutunya. Standar yang ada hanya untuk ikan segar yaitu jika kadar TVB-N lebih kecil $30 \mathrm{mgN} / 100 \mathrm{~g}$ sampel ikan dikatakan dalam keadaan segar. Jika nilainya lebih besar dari $30 \mathrm{mgN} / 100 \mathrm{~g}$ sampel maka ikan tersebut sudah mengalami kemunduran mutu. Walaupun, nilai kadar TVB-N ikan tandipang asap 
kering yang dihasilkan lebih besar $(96,60 \mathrm{mgN} / 100$ g sampel) dari standar nilai TVB-N ikan segar, tidak berarti bahwa ikan tandipang asap kering mulai mengalami pembusukan. Menurut Connel (1975) produk ikan asap jumlah TVB-N sebaiknya kurang dari $100 \mathrm{mgN} / 100 \mathrm{~g}$ sampel. Hal ini dapat dibuktikan dengan masih diterimanya produk oleh panelis setelah 40 hari penyimpanan pada kategori agak suka.

\section{Hasil Uji Hedonik}

Data hasil uji hedonik (citarasa) ikan tandipang asap kering memperlihatkan bahwa nilai tertinggi adalah 7,17 pada ikan tandipang asap kering tanpa penyimpanan, sedangkan nilai terendah adalah 6,47 pada ikan tandipang asap kering penyimpanan selama 40 hari.

Data tersebut menunjukkan bahwa tingkat kesukaan panelis terhadap citarasa ikan tandipang asap kering mengalami penurunan setelah penyimpanan 20 dan 40 hari, akan tetapi nilai tersebut menunjukkan masih pada kategori agak disukai panelis. Nilai citarasa ikan teri asap kering dari pengolah hasil penelitian Bawangun (2003) berada pada kisaran 6,30-6,48. Masih disukainya produk ini oleh panelis didukung oleh ini adanya kadar air pada produk yang masih rendah, dan nilai pH dan TVB yang masih baik.

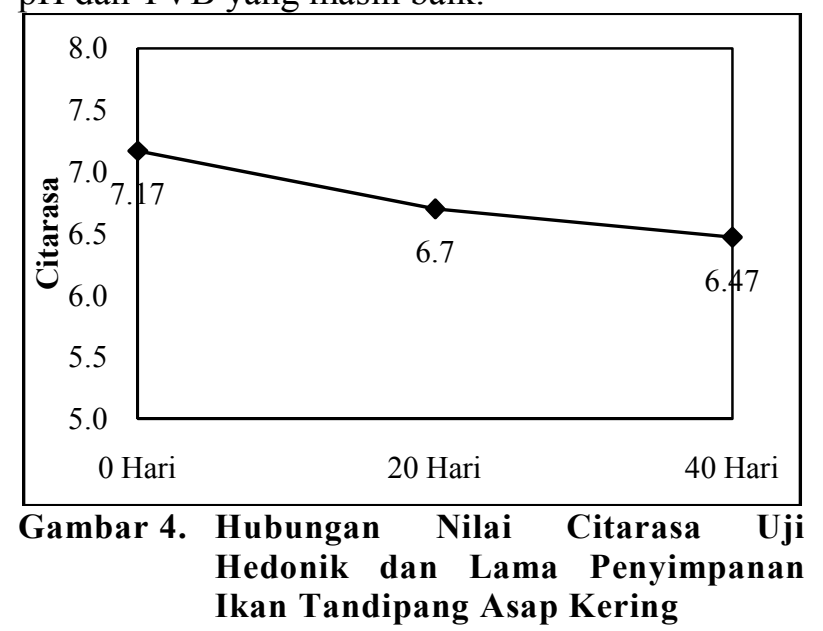

Berdasarkan gambar 4 dapat dilihat bahwa semakin lama penyimpanan tingkat kesukaan dari panelis semakin menurun. Hal ini diduga disebabkan karena kandungan air yang meningkat dan nilai $\mathrm{pH}$ yang berubah sehingga menyebabkan perubahan mutu produk. Perubahan mutu produk ini mempengaruhi tingkat kesukaan panelis terhadap produk, akan tetapi secara keseluruhan panelis masih menerima produk karena skor ratarata yang diberikan panelis masih pada kategori suka.
Kombinasi proses pengasapan dan proses pengeringan, selain ditujukan untuk pengawetan dapat juga memberikan citarasa yang lezat. Hal ini diduga dipengaruhi oleh kandungan senyawa dalam asap melalui proses pengasapan dan proses lanjutan melalui proses pengeringan. Hal ini dapat menyebabkan ikan tandipang asap kering disukai oleh panelis. Menurut Afrianto dan Liviawaty (1989) unsur fenol dan asam organik yang lebih banyak melekat pada daging ikan dapat menghasilkan rasa maupun warna daging ikan asap yang khas. Selanjutnya menurut Desrosier (1988) bahan pangan kering yang dihasilkan dari suatu alat pengering, kadar gulanya lebih tinggi dibandingkan dengan bahan segar. Hal ini dibuktikan dengan kandungan air yang berkurang lebih rendah selama proses pengeringan. Nilai gizi bahan kering lebih rendah dibandingkan dengan nilai gizi ketika bahan tersebut masih segar dan selama pengeringan dapat terjadi perubahan warna, tekstur, aroma (Harikedua, 1995).

\section{KESIMPULAN}

Proses pengolahan ikan tandipang asap kering dengan pengasapan pada suhu 70-80 0C selama 30-45 menit dan dikeringkan dengan lemari pengering bersuhu 35-45 0C selama 20 jam dapat menghasilkan produk dengan kisaran kadar air 15,20-15,70\%; pH 6,06-6,63; TVB 54,80$96,60 \mathrm{mgN} / 100$ gr sampel dan nilai uji hedonik citarasa $6,47-7,17$. Nilai kadar air produk setelah proses penyimpanan 40 hari $(15,70 \%)$ masih di bawah nilai yang disyaratkan Standar Nasional Indonesia untuk produk ikan asap (maks. 60\%) dan ikan kering (maks. 20\%). Nilai pH setelah proses penyimpanan 40 hari adalah 6,63 . Nilai TVB-N setelah proses penyimpanan 40 hari adalah 96,60 $\mathrm{mgN} / 100 \mathrm{~g}$ sampel. Citarasa ikan tandipang asap kering yang dihasilkan selama penyimpanan 40 hari masih dapat diterima oleh panelis.

\section{DAFTAR PUSTAKA}

Alasalvar, C. and T. Taylor. 2002. Seafood Quality, Technology and Association of Official Analytical Chemist (AOAC). 1984. Official Methods of Analysis. $14^{\text {th }}$ Edition. Washington DC.

Afrianto, E., dan E. Liviawaty., 1989. Pengawetan dan Pengolahan Ikan. Kanisius. Yogyakarta.

Alamsjah, R. 2001. Teknologi Pengawetan Pangan. Skripsi. Fakultas Pertanian. UNSRAT. Manado.

Anonimous. 2000. Identifikasi Dussumieria acuta (Rainbow sardine). FAO. www.fao.org/fishery/ species/2900-23k. [24 Maret 2009, jam 17.00 Wita]. 
2008 Produksi Ikan Tandipang (Dussumieria acuta C.V.) Asap Kering. Dinas Perikanan dan Kelautan Minahasa Selatan.

2009. Standarisasi Nasional Indonesia: Ikan Asap. Badan Standarisasi Indonesia. Jakarta. 2009. Standarisasi Nasional Indonesia: Ikan Teri A sin Kering. Badan Standarisasi Indonesia. Jakarta.

2011. "The Measurement of $\mathrm{pH}$ - Definition, Standards and Procedures A proposal to revise the current IUPAC 1985 and ISO 31-8 definition of $\mathrm{pH}$. Report of the Working Party on $\mathrm{pH}$, IUPAC Provisional Recommendation". http://www.iupac.org/ reports/provisional/abstract01/rondinini_prs.pdf. [25 April 2011]

Azam, K., M. Z. Basher, M. Y. Ali, M. Asaduzzaman dan M. M. Hosaain. 2003. Comparative Study of Organoleptic, Microbiology and Biochemical Qualities of Four Selected Dried Fish in Summer and Winter. Fisheries and Marine Resource Technology Discipline, Khulna University. Bangladesh. Pakistan Journal of Biological Sciences 6 (24): 2030-2033, 2003. ISSN 1028-8880.

Berhimpon, S., F. G. Ijong dan P. Moniharapon, 2002. Penilaian Indera. Penuntun Praktikum. FPIK. UNSRAT. Manado.

Berhimpon, S., H. Dien, R. Montolalu, 2002. Processing and The Prospect of Katsuobushi (Ikan kayu) of North Sulawesi, Indonesia: A Review. Fish Handling and Processing Laboratory. Faculty of Fisheries and Marine Science. Sam Ratulangi University. Manado

Bawangun, 2003. Tinjauan Mutu Ikan Teri (Stelophorus sp) Asap Kering Hasil Pengolahan Beberapa Industri Rumah Tangga di Kecamatan Tumpaan. Skripsi. Fakultas Perikanan dan Ilmu Kelautan. UNSRAT. Manado.

Buckle, K.A., R.A. Edward, G.H. Fleet, M. Wooton. 1985. Ilmu Pangan. Penerjemah Hari Purnomo dan Adiono. Universitas Indonesia. Jakarta.

Chamidah, A., Tjahyono, A. dan Rosidi, D. 2000. Penggunaan Metode Pengasapan Cair dalam Pengembangan Ikan Bandeng Asap Tradisional. Jurnal Ilmu-ilmu Teknik. Volume 12. No. 1

Desroisier, N.W. 1988. Teknologi Pengawetan Pangan. Terjemahan Muljoharjo, M. (UI-Press). Jakarta.

Hadiwiyanto. 1993. Teknik Handling dan Packing Komoditi Perikanan Darat. Bogor: IPB Press.

Hadiwiyoto, S. 1993. Teknologi Pengolahan Hasil Perikanan. Jilid 1 Liberty. Jogjakarta.

Harikedua, J. W. 1995. Pengantar Teknologi Pengolahan Hasil Perikanan. Materi Kuliah. Fakultas Perikanan dan Ilmu Kelautan. Universitas Sam Ratulangi. Manado.
2002. Metode Analisis Kimia Hasil Perikanan. Penuntun Praktikum. Fakultas Perikanan dan Ilmu Kelautan. Universitas Sam Ratulangi. Manado.

Irawan, A., 1995. Pengolahan Hasil Perikanan Home Industri. C.V. Aneka. Solo.

Junianto. 2003. Teknik Penanganan Ikan. Jakarta: Penebar Swadaya.

Moeljanto, R. 1992. Pengolahan dan Pengawetan Hasil Perikanan. Penebar Swadaya. Jakarta.

Muchtadi, D. 1989. Evaluasi Nilai Gizi Pangan. Petunjuk Laboratorium. PAU Pangan dan Gizi. IPB. Bogor.

Nurcahya, E. dan R. Ibrahim. 2008. Mutu dan Daya Simpan Fillet Dendeng Ikan Nila Merah Yang Dikemas Hampa Udara Dengan Vacuum Sealer Skala Rumah Tangga. Fakultas Perikanan dan Ilmu Kelautan Universitas Diponegoro. Jurnal Saintek Perikanan Vol. 4 No. 12008 : 7 - 15. Fakultas Perikanan.

Panjaitan, R. 2006. Pengaruh Penambahan Sereh (Cymbopogan citratus) Terhadap Mutu Ikan Layang (Decapterus sp) Asap Selama Penyimpanan Pada Suhu Kamar. Skripsi. Fakultas Perikanan dan Ilmu Kelautan. UNSRAT. Manado.

Peranginangin, R. 1983. Penelitian Dendeng Tawes (Pintius javanicus) dalam Berbagai Bentuk Olahan. Laporan Penelitian Teknologi Perikanan. Balai Pengembangan Pertanian. Departemen Pertanian. Jakarta.

Pure, A. C. 1985. Definitions of $\mathrm{pH}$ scales, standard reference values, measurement of $\mathrm{pH}$, and related terminology. Jurnal 57, pp 531-542. http://id.wikipedia.org/wiki/pH. [29 April 2011].

Soekarto, S.T.1990. Penilaian Organoleptik untuk Industri Pangan dan Hasil Pertanian. Jakarta: Bhratara Karya Aksara.

Sudarmadji, S., Bambang Haryono, Suhardi,. 1984. Prosedur Analisa Untuk Bahan Makanan dan Pertanian. Liberty. Yogyakarta.

Suwetja, K. I. 1993. Metode Penentuan Mutu Ikan. Jilid I. Penentuan Kesegaran. Fakultas Perikanan dan Ilmu Kelautan. Universitas Sam Ratulangi. Manado.

Tangkabiringan, E. S. F. 1991. Penentuan Mutu Ikan Cakalang Asap Yang Dipasarkan di Beberapa Pasar di Kotamadya Manado. Laporan Hasil Penelitian. Fakultas Perikanan. UNSRAT. Manado

Wibowo, S. 2000. Industri Pengasapan Ikan. Penebar Swadaya. Jakarta.

Winarno, F. G. 1993. Pangan (Gizi, Teknologi dan Konsumen). Gramedia Putaka Utama. 